\title{
Bevacizumab/Interferon Alfa Regimen
}

National Cancer Institute

\section{Source}

National Cancer Institute. Bevacizumab/Interferon Alfa Regimen. NCI Thesaurus. Code C12075.

A regimen consisting of bevacizumab and interferon-alfa that can be used for the treatment of advanced renal cell carcinoma (RCC). 